\title{
Magentite particles change electrical properties of a porcine heart tissue
}

\section{Las partículas de magnetita cambian las propiedades eléctricas de un tejido cardíaco porcino}

\author{
SOLIS-ROJAS, Michelle ${ }^{1}$, MORENO GONZÁLEZ-TERAN, Gustavo ${ }^{2}$, GÓMEZ-SOLIS, Christian², \\ GALINDO-GONZÁLEZ, Rosario ${ }^{3}$ and BALLEZA-ORDAZ, José Marco ${ }^{2}$
}

${ }^{1}$ Universidad Politécnica del Bicentenario

${ }^{2}$ División de Ciencias e Ingenierías, Universidad de Guanajuato

${ }^{3}$ División de Ciencias Naturales y Exactas, Universidad de Guanajuato

ID $1^{\text {st }}$ Author: Michelle, Solis-Rojas / ORC ID: 0000-0001-8551-6767

ID $1^{\text {st }}$ Coauthor: Gustavo, Moreno González-Teran / ORC ID: 0000-0002-1959-1571

ID $2^{\text {nd }}$ Coauthor: Christian, Gómez-Solis / ORC ID: 0000-0002-7860-3536, CVU CONACYT ID: 210658

ID $3^{\text {er }}$ Coauthor: Rosario, Galindo-González / ORC ID: 0000-0002-3612-1555, CVU CONACYT ID: 223987

ID $4^{\text {th }}$ Coauthor: José Marco, Balleza-Ordaz / ORC ID: 0000-0002-3246-0277, CVU CONACYT ID: 406536

DOI: $10.35429 /$ JRD.2019.15.5.38.40

Received: March 17, 2019; Accepted: May 22, 2019

Abstract

Objectives. Electrical impedance spectroscopy (EIS) is a harmless non-invasive technique that allows to measure and monitor different physiological parameters. One of the problems with establishing new procedures based on EIS is difficulty to distinguish between tissue types. For that reason, our research group have decided to assess a possibility to use nanomagnetite as a contrast medium in EIS procedures. In this work we present characterization the electrical properties of a porcine heart tissue by EIS using a magnetite particles suspension as contrast medium. Methodology. SP-150 from BioLogic Science Instruments was used as EIS equipment. Porcine heart tissue was used as biological tissue. Nanomagnetite particles were synthetized by coprecipitation and combustion methods and named NM1 and NM2, respectively. EIS device was connected at each ventricle through four hypodermic needles $(38 \mathrm{~mm})$. Left and right ventricle was injected with NM1 and NM2 particles, respectively. Impedance measurements were acquired for each ventricle before and after the injection. Contribution. Both samples of magnetite nanoparticles were able to change electrical properties of heart tissue. Studies in vivo must be performed in order to confirm the conclusion.

Biological tissue, Electrical impedance, Nanomagnetite
Resumen

Objetivos. La espectroscopia de impedancia eléctrica (EIS) es una técnica no dañina y no invasiva que permite medir y monitorizar diferentes parámetros fisiológicos. Uno de los problemas para establecer nuevos procedimientos basados en EIS es dificultad en distinguir entre los tipos de tejido. Por esa razón, nuestro grupo de investigación ha decidido evaluar la posibilidad de usar nanomagnetita como medio de contraste en los procedimientos de EIS. En este trabajo presentamos la caracterización de las propiedades eléctricas de un tejido cardíaco porcino mediante EIS utilizando una suspensión de partículas de magnetita como medio de contraste. Metodología. SP-150 de BioLogic Science Instruments se usó como equipo EIS. Se utilizó tejido cardíaco porcino como tejido biológico. Las partículas de nanomagnetita se sintetizaron mediante métodos de coprecipitación y combustión y se denominaron NM1 y NM2, respectivamente. El dispositivo EIS se conectó en cada ventrículo a través de cuatro agujas hipodérmicas (38 $\mathrm{mm}$ ). Los ventrículos izquierdo y derecho se inyectaron con partículas NM1 y NM2, respectivamente. Se adquirieron mediciones de impedancia para cada ventrículo antes y después de la inyección. Contribución. Ambas muestras de nanopartículas de magnetita pudieron cambiar las propiedades eléctricas del tejido del corazón. Se deben realizar estudios in vivo para confirmar la conclusión.

Tejido biológico, Impedancis eléctrica, Nanomagnetita

Citation: SOLIS-ROJAS, Michelle, MORENO GONZÁLEZ-TERAN, Gustavo, GÓMEZ-SOLIS, Christian, GALINDOGONZÁLEZ, Rosario and BALLEZA-ORDAZ, José Marco. Magentite particles change electrical properties of a porcine heart tissue. Journal of Research and Development. 2019, 5-15: 38-40.

\footnotetext{
* Correspondence to Author (hferreira@iies.unam,mx)

$\dagger$ Researcher contributing first Author.
} 


\section{Introduction}

Nanoparticles composed by different metals have been extensively investigated to be used in different biomedical applications. The applications include biomedical imaging, drug delivery, colorimetric biosensing, etc. Then synthesised properly, metal nanoparticles exhibit low cytotoxicity and less susceptibility to oxidation. For instance, gold nanoparticles have received great attention as contrast in multiple imaging techniques due to its high atomic number and X-ray absorption coefficient. Similarly, nanometric form of magnetite have emerged recently as contrast medium in magnetic resonance imaging because of its supermagnetic and surface properties and biodegradability. In summary, metal nanoparticles are emerging as imaging agents for different techniques.

On the other hand, our research group work is developing new medical diagnostic procedures based on electrical impedance spectroscopy (EIS). EIS is a noninvasive technique that is used to obtain the characterization and electrical properties of biological and nonbiological materials in frequency domain through electrodes. Due to complex nature of impedance, two important parameters of EIS measurements can be highlighted: module and phase. Module can provide information about changes in the volume of tissue and phase reflects changes of cellular structure. The technique is noninvasive, harmless and relatively cheap. One of the problems with establishing new procedures based on EIS is difficulty in distinguishing between tissue types. For that reason, our research group have decided to assess a possibility to use nanomagnetite as a contrast medium in EIS procedures.

In this work we present characterization the electrical properties of a porcine heart tissue by EIS using a magnetite particles suspension as contrast medium.

\section{Methodology}

Materials. SP-150 from BioLogic Science Instruments was used as EIS equipment. Porcine heart tissue was purchased as fresh as possible at local market and used as biological tissue.
Nanomagnetite particles were synthetized by coprecipitation and combustion methods and named NM1 and NM2, respectively (Figure 1). Hypodermic needles $(38 \mathrm{~mm})$ were implemented as electrodes.

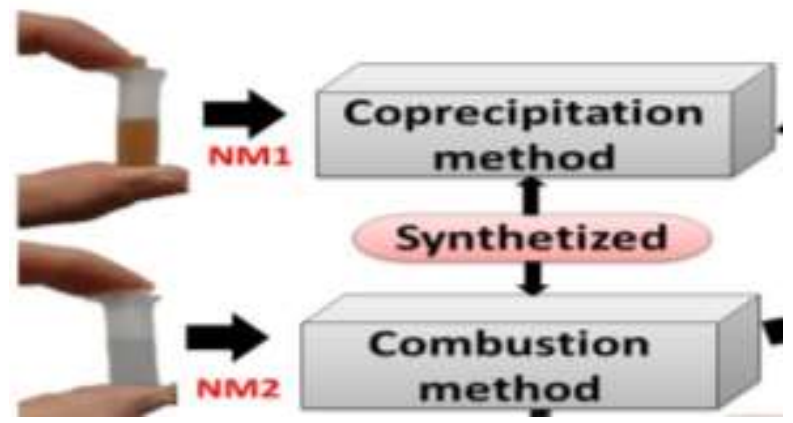

Figure 1 Magnetite nanoparticles and methods of synthesis

Methods. NM1 and NM2 were suspended in sterile physiological solution at concentration $1 \mathrm{mg} / \mathrm{mL}$ and injected to the biological tissue separately. EIS measurements were performed before and after the injection. Figure 2 depicts generally the methodology used in this study. All data was analysed by Bode graphics (impedance and phase) at $50 \mathrm{kHz}$ frequency.

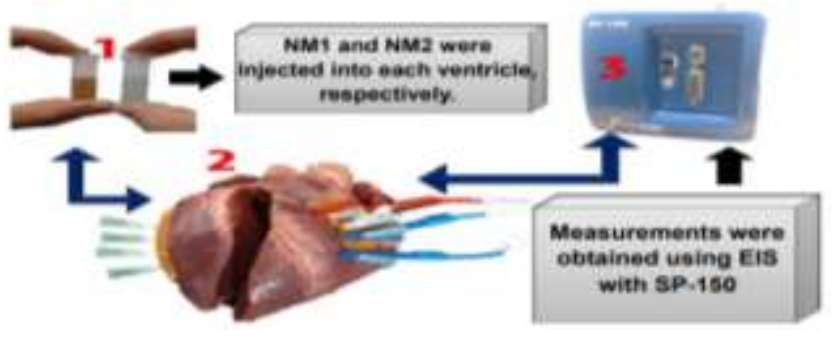

Figure 2 Measurement process in porcine tissue under the influence of magnetite nanoparticles

\section{Results}

Scanning electron microscopy have shown that particle of both samples NM1 and NM2 were well dispersed and have irregular shape. The size of obtained particles were less than 100 nm.

Raman spectra of NM1 and NM2 are shown at figure 3 . It can be observed, that both samples present similar peak pattern, so it can be concluded that their chemical composition is the same. 


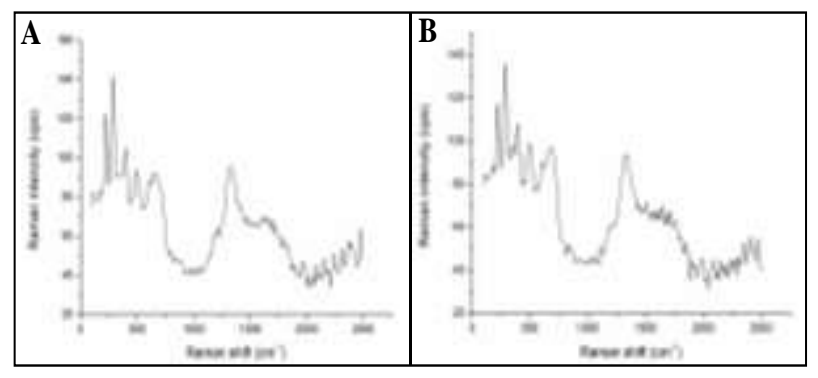

Figure 3 Raman spectroscopy for NM1 (A) and NM2 (B)

The mean value of impedance (phases) at basal biological stage of left and right ventricles were of $287.7 \Omega\left(-53.12^{\circ}\right)$, and 421.8 $\Omega\left(-65.3^{\circ}\right)$, respectively. The mean value of impedance-module and phases in the left ventricle with NM1 and right ventricle with $\mathrm{NM} 2$ were of $156.36 \Omega\left(-60.24^{\circ}\right)$ and $141.8 \Omega(-$ $\left.57.90^{\circ}\right)$, respectively. The comparative graphs between phases and frequencies are shown in figures 4 and 5 .

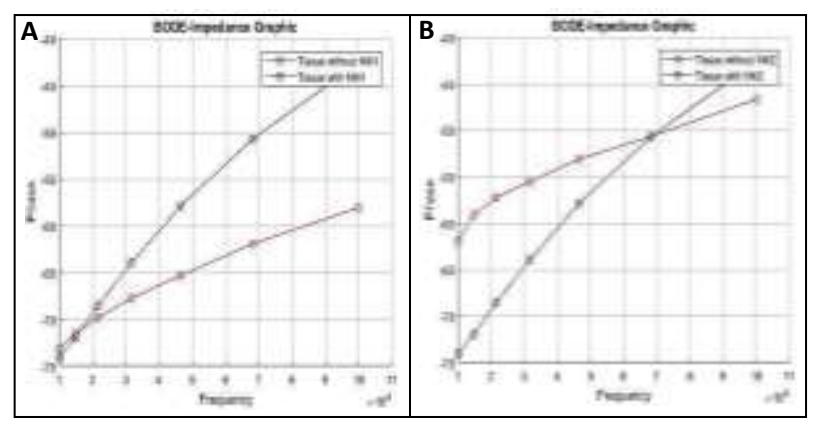

Figure 4 Phase graphs between basal state and under the influence of nanoparticles

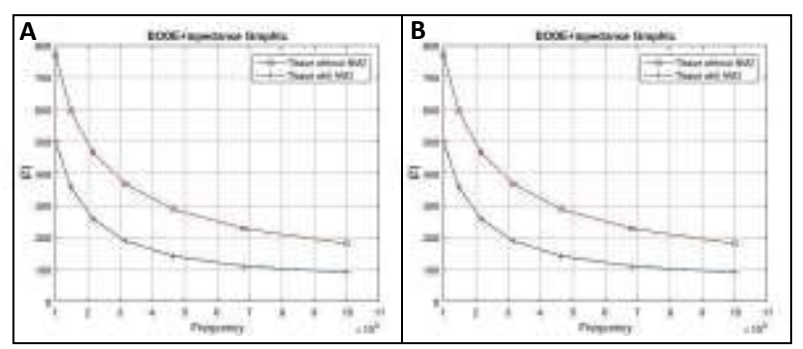

Figure 5 Module $(|\mathrm{Z}|)$ graphs between basal state and under the influence of nanoparticles

\section{Conclusions}

It can be concluded that both samples of magnetite nanoparticles were able to change electrical properties of heart tissue. Studies in vivo must be performed in order to confirm the conclusion.

\section{References}

Nune, S. K., Gunda, P., Thallapally, P. K., Lin, Y. Y., Laird Forrest, M., \& Berkland, C. J. (2009). Nanoparticles for biomedical imaging. Expert opinion on drug delivery, 6(11), 1175-1194.

Stephen, Z. R., Kievit, F. M., \& Zhang, M. (2011). Magnetite nanoparticles for medical MR imaging. Materials Today, 14(7-8), 330338 .

Vilos, C., Gutiérrez, M., Escobar, R. A., Morales, F., Denardin, J. C., Velasquez, L., \& Altbir, D. (2013). Superparamagnetic Poly (3hydroxybutyrate-co-3 hydroxyvalerate) (PHBV) nanoparticles for biomedical applications. Electronic Journal of Biotechnology, 16(5), 8-8. 